
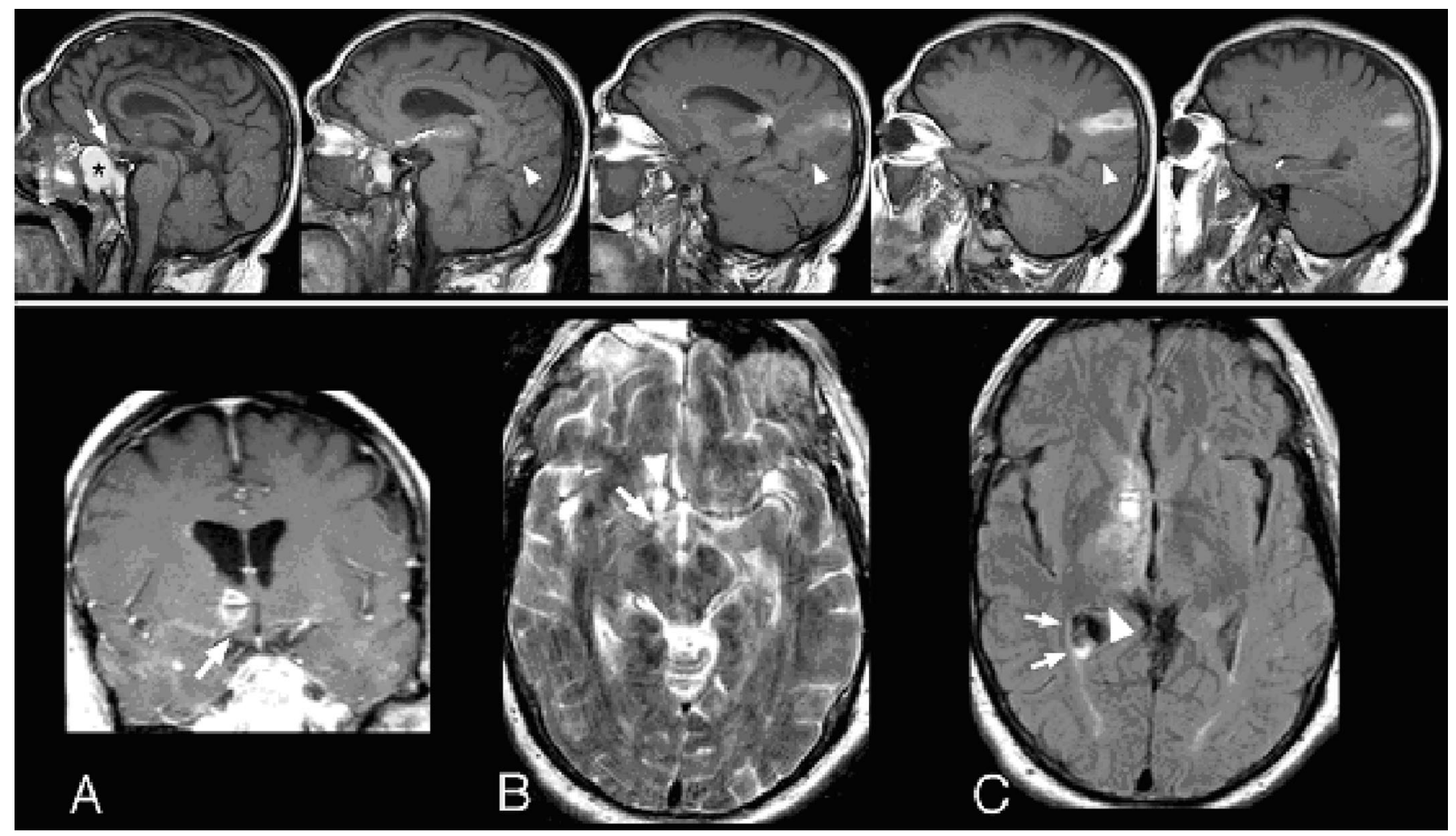

Figure. Top panel (left to right): Nonenhanced sagittal T1 image shows that the catheter has left an irregular line, a trail of hemorrhage (seen as hyperintense signal) from its entry point in the superior sphenoid sinus anterior to the sella turcica (leftmost image; arrow), through the right inferior frontal lobe and thalamus, and on through the lateral ventricle to the posterosuperior right parietal lobe. Hemorrhage is seen within the sphenoid sinus (leftmost image; black asterisk). The catheter trail runs above the parieto-occipital fissure (arrowheads), and therefore does not involve the occipital lobe. There is a small collection of subacute blood at the tip of the inferior horn (rightmost image). Bottom panel: (A) right frontal hemorrhage lies immediately superior to the right optic tract (enhanced coronal T1 image); (B) right optic tract shows abnormally increased signal (arrow) adjacent to catheter trail (arrowhead; T2 axial image); (C) the optic radiations (arrow) and lateral geniculate (arrowhead) are not within the catheter trajectory and are thus spared (FLAIR axial image).

\section{Homonymous hemianopsia complicating treatment of postoperative epistaxis}

Patricio S. Espinosa, MD, MPH; Charles D. Smith, MD; and Joseph R. Berger, MD, Lexington, $K Y$

Following biopsy of a malignancy in the right nasal cavity of a 60 -year-old man, a 22-French Foley was inserted to stem postoperative bleeding that failed to resolve with posterior nasal packing. A CT scan was obtained after the second attempt at passage

Disclosure: The authors report no conflicts of interest.

Address correspondence and reprint requests to Dr. Patricio S. Espinosa, Department of Neurology, Kentucky Clinic (Room L-445), Lexington, KY 40536-0284; e-mail: psespi2@email.uky.edu of the Foley, revealing that the catheter had traversed the cribriform plate and left a pneumocephalic trail through the brain with traumatic hemorrhage seen in the right lateral ventricle and occipital lobe. On neurologic examination, the patient was confused and had a complete left homonymous hemianopia on confrontational visual fields. Brain imaging showed that the right optic tract was injured; the optic radiations, lateral geniculate, and occipital lobe were spared (figure). The patient was discharged home for outpatient radiation therapy for an undifferentiated sinonasal carcinoma.

Direct penetrating trauma to the brain is an unusual complication of catheter insertion to stanch bleeding from the nasal cavity. ${ }^{1}$

1. Shults WT, Hamby S, Corbett JJ, Kardon R, Winterkorn JS, Odel JG. Neuro-ophthalmic complications of intracranial catheters. Neurosurgery 1993;33:135-138. 


\section{Neurology}

\section{Homonymous hemianopsia complicating treatment of postoperative epistaxis}

Patricio S. Espinosa, Charles D. Smith and Joseph R. Berger

Neurology 2006;67;1305

DOI 10.1212/01.wnl.0000221735.19760.eb

\section{This information is current as of October 9, 2006}

\section{Updated Information \&} Services

References

Subspecialty Collections

Permissions \& Licensing

Reprints including high resolution figures, can be found at: http://n.neurology.org/content/67/7/1305.full

This article cites 1 articles, 0 of which you can access for free at: http://n.neurology.org/content/67/7/1305.full\#ref-list-1

This article, along with others on similar topics, appears in the following collection(s):

MRI

http://n.neurology.org/cgi/collection/mri

Visual fields

http://n.neurology.org/cgi/collection/visual_fields

Information about reproducing this article in parts (figures,tables) or in its entirety can be found online at:

http://www.neurology.org/about/about_the_journal\#permissions

Information about ordering reprints can be found online:

http://n.neurology.org/subscribers/advertise

Neurology ${ }^{\circledR}$ is the official journal of the American Academy of Neurology. Published continuously since 1951, it is now a weekly with 48 issues per year. Copyright . All rights reserved. Print ISSN: 0028-3878. Online ISSN: 1526-632X.

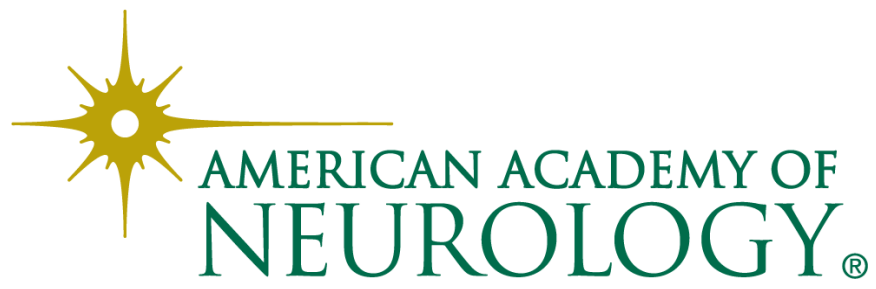

